\title{
АНАЛІЗ ЗСУВНИХ ПРОЦЕСІВ В УКРАЇНІ ТА ЗАХОДИ ЇХНЬОГО УСУНЕННЯ
}

\author{
ANALYSIS OF LANDSLIDE IN UKRAINE \\ AND METHODS OF THEIR ELIMINATION
}

\author{
Линник І.Е., д.т.н., проф., Шмуля І.А., студентка, (Харківський \\ національний \\ університет \\ міського \\ господарства \\ імені \\ О. М. Бекетова)
}

\section{Lynnyk I.E., Doctor of Engineering, Professor, Shmulya I.A., student, (O. M. Beketov National University of Municipal Economy in Kharkiv)}

Анотація. Проведено аналіз зсувних прочесів на території Украӥни та Харківської області. У місті Харкові зсувонебезпечні території розтамовані переважно на берегах річок Лопань, Харків та схилах ярів Олексіївська балка, Чуніхін Яр тощо. Як проектна пропозиція запропоновано проведення інженерного захисту берегової смуги уздовж р. Немишля.

Summary. Landslides are a dangerous physico-geological phenomenon that leads to the destruction of buildings, engineering structures and the death of people. The study of landslide processes not only in Ukraine but in the whole world is an urgent problem both during the construction of new objects and during the exploitation of already built ones.

In article the analysis of landslide processes in the territory of Ukraine was carried out, which revealed that the spread and development of landslides has a tendency to increase, and the landslide zones in the last 30 years have increased by 2-5 times. The most common are landslides in the Crimea, Transcarpathian, Ivano-Frankivsk, Lugansk, Odesa, Lviv, Mykolaiv, Kharkiv, Cherkasy and Chernivtsi regions. Volyn and Rivne regions have no geological preconditions for the development of the landslide process at all.

In article the analysis of landslide processes in the Kharkiv region was carried out. As a result, it was found that 1615 landslides with a total area of 40,3 km2 were recorded on its territory, two of them, with an area of 0,09 $\mathrm{km} 2$, are active. In Kharkiv landslide areas are located mainly on the banks of the rivers Lopan, Kharkiv and the slopes of ravines Oleksiivska Beam, Chunikhin Yar, etc.

In article as a project proposal, it is proposed to conduct engineering protection of the coastal strip along the Nemyshlya River. For this purpose, construction is proposed on the right bank, where there is a significant difference in the height, construction of reinforced concrete retaining wall. In the sole of this wall is proposed to lay coastal drainage. On the left bank of the Nemyshlya river the slope is more gentle. Therefore, it is proposed to install a three-dimensional geogrid on this shore. And then, on the thus formed topography of the shore, the grass is sown. As a result of engineering protection, the coastline can be used as a recreational area for the rest of the population. 
Ключові слова: зсувні процеси, заходи усунення зсувів

Keywords: landslide processes, methods of landslide removal

Постановка проблеми. Зсуви $є$ небезпечним фізико-геологічним явищем, яке призводить до руйнування будівель, інженерних споруд, а також до загибелі людей. Тому дослідження зсувних процесів не тільки в Україні, але й у всьому світі $є$ актуальною проблемою як під час будівництва нових об'єктів, так і під час експлуатації вже збудованих $[1,2]$.

Аналіз відомих досліджень і публікацій. Дослідження зсувних процесів, прогнозування їхнього розвитку і способи боротьби із ними проводяться багатьма вченими різних країн світу [3-9]. Систематичне спостереження за зсувами, і своєчасна боротьба з ними, дозволяє запобігти руйнуванню укосів, схилів, не допустити загрози аварійних ситуацій у будівлях і спорудах, тобто уникнути людських жертв. Але незважаючи на це, за статистикою кількість загиблих у всьому світі від зсувних процесів збільшується 3 кожним роком. Згідно 3 дослідженнями, кількість жертв збільшилася в 10 разів, ніж вважалося раніше.

Мета статті: проаналізувати зсувні процеси в Україні i, зокрема, Харківській області та запропонувати інженерний захист зсувонебезпечної берегової смуги уздовж р. Немишля в м. Харкові.

Відповідно до поставленої мети вирішуються наступні завдання:

- проаналізувати зсувні процеси в Україні, Харківській області і місті Харкові та навести методи боротьби зі зсувами;

- запропонувати заходи 3 ліквідації зсувів на p. Немишля (Московський район, вул. Самсонівська) в м. Харкові та висунути пропозиції щодо використання зсувної території.

Аналіз зсувних процесів в Україні. Поширення та розвиток зсувів на території України має тенденцію до зростання, зокрема площі зсувонебезпечних зон за останні 30 років збільшились у 2-5 разів. Згідно даних Державної служби геології та надр України на території України зафіксовано 22958 зсуви (рис. 1), із них активних зсувів - 1116 (рис. 2) [10]. Загальна площа зсувних ділянок становить 2 135,45 км² (рис. 3), із них в активному стані - 79,08 км² (рис. 4) [10]. У зонах зсувів знаходяться 1638 об'єктів господарської діяльності.

3 аналізу діаграм можна зробити висновок, що найбільш поширеними є зсуви у Криму, Закарпатській, Івано-Франківській, Луганській, Одеській, Львівській, Миколаївській, Харківській, Черкаській і Чернівецькій областях за винятком Волинської та Рівненської, які взагалі не мають геологічних передумов для розвитку зсувного процесу.

Загальна сума втрат від зсувів за останні 30 років сягає близько 85 млн грн., зокрема у Січеславській обл. - понад 35 млн грн., Луганській обл. - близько 22 млн грн., у Чернівецькій обл. - понад 20 млн грн. 
Значних збитків від активізації процесу зазнають міста Київ, Кам'янське, Дніпро, Запоріжжя, Одеса, Чернігів, Полтава, Чернівці та інші [10].

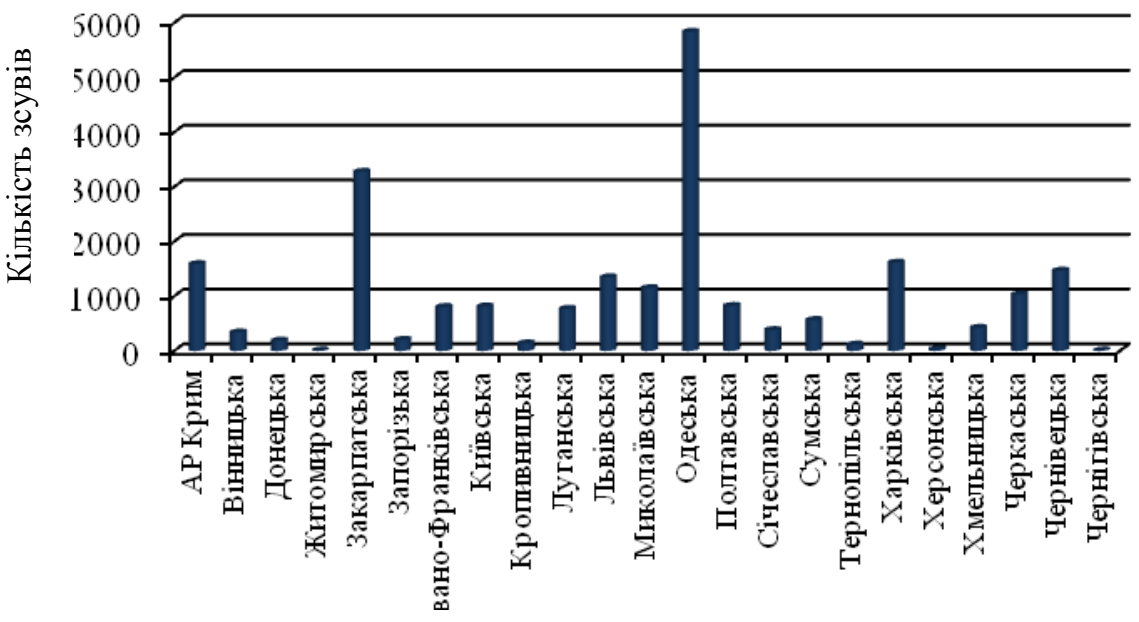

Адміністративні області України

Рис. 1. Загальна кількість зсувів у межах адмінодиниць України

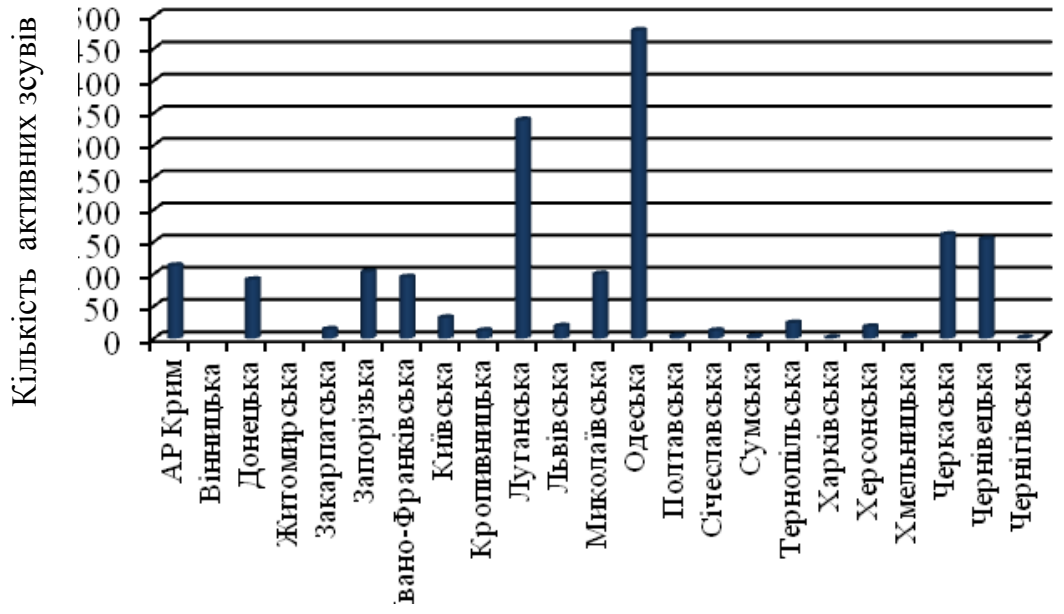

Адміністративні області України

Рис. 2. Кількість активних зсувів у межах адмінодиниць України 


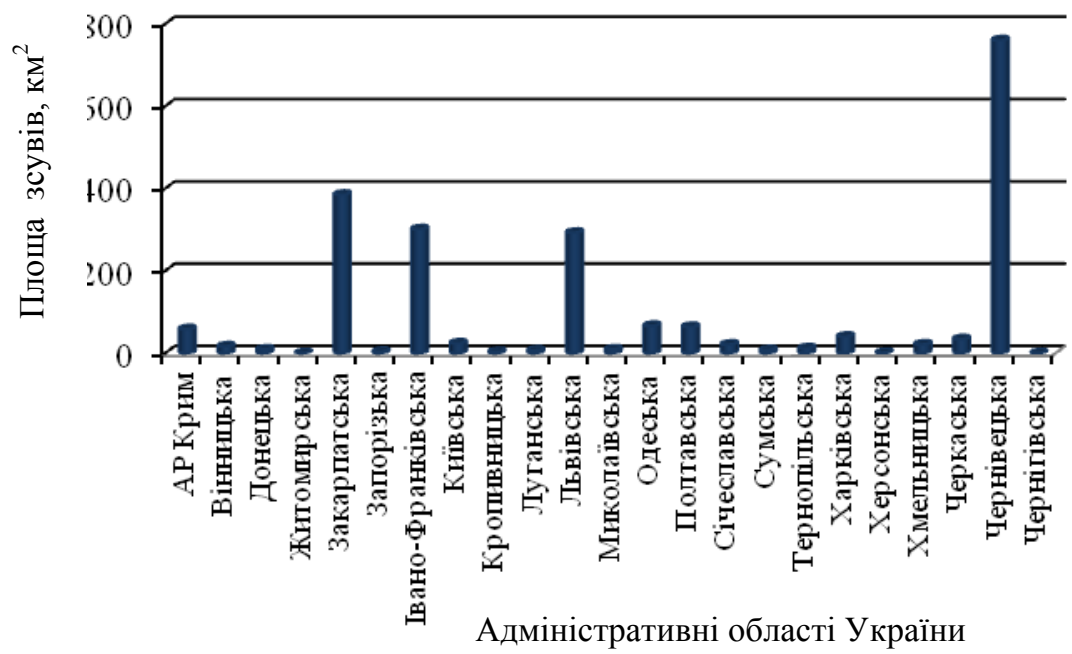

Рис. 3. Загальна площа зсувів у межах адмінодиниць України

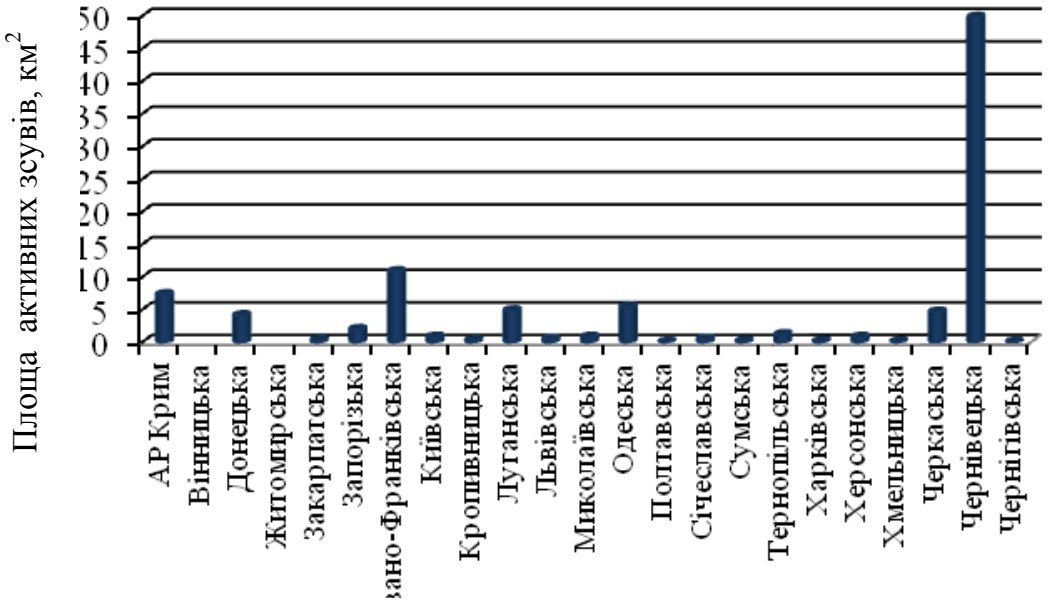

Адміністративні області України

Рис. 4. Площа активних зсувів у межах адмінодиниць України

Сучасна активізація зсувів викликана цілою низкою природних $\mathrm{i}$ техногенних причин. Техногенний характер виникнення, розвитку та активізації зсувів завдає економіці держави значних збитків. Розташування 
інженерних об'єктів на схилах чи поблизу них $є$ провокуючим чинником, який призводить до порушення рівноваги у масиві порід, i, як наслідок, до активізації зсувів.

Аналіз зсувних процесів у Харківській області і м. Харкові. У Харківській області зафіксовано 1615 зсувів загальною площею 40,3 км², 3 них 11 , площею $0,011 \mathrm{kм}^{2} \epsilon$ активними [10]. На забудованій території знаходяться 68 зсувів.

У м. Куп'янську нових зсувних проявів не виявлено, але залишається активним Голубівський зсув. Низька зсувна активність відзначається в м. Краснокутську. У селищі Крейдяна Балаклійського району зрушення по вул. Підлісній залишається активним.

На території міста Харкова досить розвинена водна й вітрова ерозія, тому, як наслідок, є багато ділянок із зсувами та зсувонебезпечними територіями (табл. 1) [11].

Таблиця 1

Зсувонебезпечні ділянки м. Харкова [11]

\begin{tabular}{|c|c|c|}
\hline $\begin{array}{l}\text { Номер } \\
\text { ділянки }\end{array}$ & $\begin{array}{l}\text { Площа } \\
\text { зсувоне } \\
\text { безпечн } \\
\text { ої зони, } \\
\text { га }\end{array}$ & Характеристика та рекомендації \\
\hline 1 & 2 & 3 \\
\hline $\begin{array}{l}\text { Ділянка } \\
\text { № } 1\end{array}$ & 20 & $\begin{array}{l}\text { Журавлівські схили в районі навчального корпусу } \\
\text { ХДПУ (від вул. Манізера до вул. Дегтярної). II } \\
\text { категорія ризику. Рекомендовано закласти мережу й } \\
\text { організувати режимні спостереження за динамікою } \\
\text { змінення порід, коливанням рівня грунтових вод }\end{array}$ \\
\hline $\begin{array}{l}\text { Ділянка } \\
\text { № } 2\end{array}$ & 3,0 & $\begin{array}{l}\text { Журавлівські схили, вул. Омська, 67. III категорія } \\
\text { ризику. Рекомендовано закласти геодезичну сітку, } \\
\text { організувати дренаж і виконати комплекс заходів } 3 \\
\text { агролісомеліорації }\end{array}$ \\
\hline $\begin{array}{l}\text { Ділянка } \\
\text { № } 3\end{array}$ & 15 & $\begin{array}{l}\text { Балка Олексіївська в районі мосту (вул. Дерев'янка). } \\
\text { III категорія ризику. Рекомендовано встановити } \\
\text { технічний контроль за станом конуса на ділянці } \\
\text { примикання дороги до гаражів і насипних схилів }\end{array}$ \\
\hline $\begin{array}{l}\text { Ділянка } \\
\text { № } 4\end{array}$ & 1,0 & $\begin{array}{l}\text { Шевченківський район, провулок Кравцова. I } \\
\text { категорія ризику. Рекомендовано організувати } \\
\text { геодезичну мережу (грунтові та настінні репери) }\end{array}$ \\
\hline $\begin{array}{l}\text { Ділянка } \\
\text { № } 5\end{array}$ & 2,5 & $\begin{array}{l}\text { Лівий схил долини р. Лопань (вул. Клочківська) в } \\
\text { районі 7-ї міської лікарні. І категорія ризику. } \\
\text { Рекомендовано цю ділянку включити в систему } \\
\text { моніторингу та проводити періодичні обстеження } 3 \\
\text { метою виявлення змін у стійкості схилів }\end{array}$ \\
\hline
\end{tabular}


Продовження таблиці 1

\begin{tabular}{|c|c|c|}
\hline 1 & 2 & 3 \\
\hline $\begin{array}{l}\text { Ділянка } \\
\text { № } 6\end{array}$ & 0,01 & $\begin{array}{l}\text { Балка Чуніхін Яр (в районі пр. Олександрівський і } \\
\text { вул. Северина Потоцького). I категорія ризику. } \\
\text { Рекомендовано періодичне візуальне обстеження } \\
\text { території }\end{array}$ \\
\hline $\begin{array}{l}\text { Ділянка } \\
\text { № } 7\end{array}$ & 6,0 & $\begin{array}{l}\text { Журавлівські схили (вул. Студентська). II категорія } \\
\text { ризику. Рекомендовано встановити } \\
\text { спостережень за динамікою деформації } \\
\text { гуртожитку ХНАДУ }\end{array}$ \\
\hline $\begin{array}{l}\text { Ділянка } \\
\text { № } 8\end{array}$ & $\begin{array}{l}\text { менше } \\
0,3\end{array}$ & $\begin{array}{l}\text { Селище Лідне. I категорія ризику. Рекомендовано } \\
\text { виконати комплекс інженерно-технічних вишукувань } \\
\text { за умови будівельного освоєння }\end{array}$ \\
\hline $\begin{array}{l}\text { Ділянка } \\
\text { № } 9\end{array}$ & 0,12 & $\begin{array}{l}\text { Київський район (вул. Шишківська). III категорія } \\
\text { ризику. Рекомендовано організувати режимні } \\
\text { iнструментальні спостереження за динамікою } \\
\text { розвитку зсуву }\end{array}$ \\
\hline
\end{tabular}

У межах міста зсувонебезпечні території поділяютья на три категорії (рис. 5):

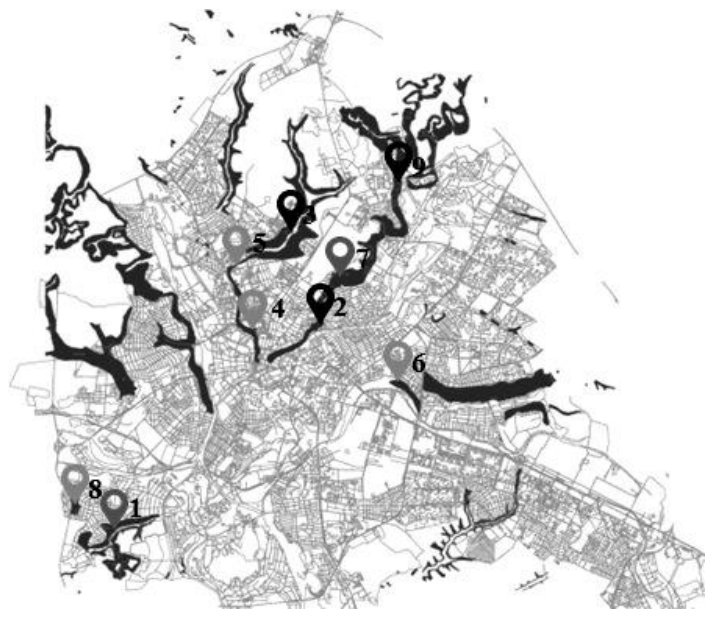

Рис. 5. Зсувонебезпечні ділянки на території міста Харкова:

$$
\begin{aligned}
& \text { - І категорії; } \quad \text { - ІІ категорії; } \\
& \text { I - слабкого ризику }-158,5 \text { км }(92,7 \%) ; \\
& \text { II - суттевого ризику - } 11,2 \text { км }(6,5 \%) ;
\end{aligned}
$$


III - екстремальної ситуації - 1,3 км (0,8 \%) (ця категорія встановлена тільки в Шевченківському районі на ділянці примикання автодорожнього мосту до правого схилу Олексіївської балки по вул. Дерев'янка і в Київському районі - Журавлівські схили на території Політехнічного університету).

У м. Харкові зсувонебезпечні території розташовані переважно на берегах річок Лопань і Харків та схилах ярів Олексіївська балка, Чуніхін Яр тощо. Це обумовлено інженерно-геологічними умовами Харківської області, антропогенними та природними факторами. У цілому територія міста сприятлива для господарського освоєння схилів.

Заходи усунення зсувів. Боротьба із зсувами в багатьох випадках $\epsilon$ надзвичайно складною, зазвичай неефективною та дорогою. Для успішного застосування протизсувних заходів необхідне високоякісне виконання інженерно-геологічних вишукувань для оцінки фактичного ступеня стійкості схилу $[1,2,6-9,12]$.

Заходи боротьби із зсувами можуть бути спрямовані як на збереження, так і на поліпшення природних властивостей і напруженого стану грунтів.

Збереженню механічних властивостей грунтів сприяє регулювання поверхневого стоку (улаштування зливової каналізації, нагірних канав, огороджувальних валів, протифільтраційні заходи), запобігання витоку із водопровідних та каналізаційних мереж $[1,2,12]$.

Для збереження напруженого стану укосів недопустиме їхне підрізання при влаштуванні доріг. Велике значення мають берего- та дноукріплювальні роботи в межах ділянки, що прилягає до схилу дна ріки чи яру. Недопустимо зводити важкі споруди в межах верхньої частини схилів та поблизу їхньої верхньої бровки $[1,2,6-9,12]$. Поліпшити механічні властивості грунтів на схилі можна за допомогою осушення (дренаж, електроосмос, випалювання, заморожування, електродренаж чи електрохімічне закріплення) [1, 2, 6-9, 12].

Щоб змінити напружений стан порід, що складають схили, зменшують крутизну укосів. У тих випадках, коли видалити породи 3 верхньої частини неможливо (при наявності тих чи інших споруд), роблять привантаження нижньої частини схилу $[1,2,6-9,12]$.

Для утримання грунтів від зсуву застосовують підпірні стінки, удержуючі пальові конструкції, буронабивні залізобетонні палі, контрбанкети, контрфорси, анкерне і нагельне кріплення, металеві сітки, геомати тощо [1, 2, 6-9, 12].

У багатьох регіонах України, де розповсюджені зсуви, розроблено генеральні схеми протизсувних заходів та намічено першочергові дії для захисту територій. Відповідно до Генеральної схеми протизсувних заходів на чорноморському узбережжі були вивчені екзогенетичні процеси в трьох областях півдня України - Одеській, Миколаївській, Херсонській і 
зазначено шляхи протизсувної боротьби. Вибір засобів захисту територій та їхні обсяги визначаються особливостями інженерно-геологічних умов окремих районів узбережжя. Перевага надається спорудам активного захисту, наприклад, для захисту одеського узбережжя потрібно споруджувати штучні пляжі, гідротехнічні траверси й підводні хвилеломи.

Проектна пропозиція інженерного захисту зсувонебезпечної берегової смуги уздовж р. Немишля в м. Харкові. Згідно проведеного аналізу зсувонебезпечних територій у м. Харкові запропоновано проведення інженерного захисту берегової смуги уздовж р. Немишля (рис. 5, ділянка 6), детальніше розглянутої на рис. 6.

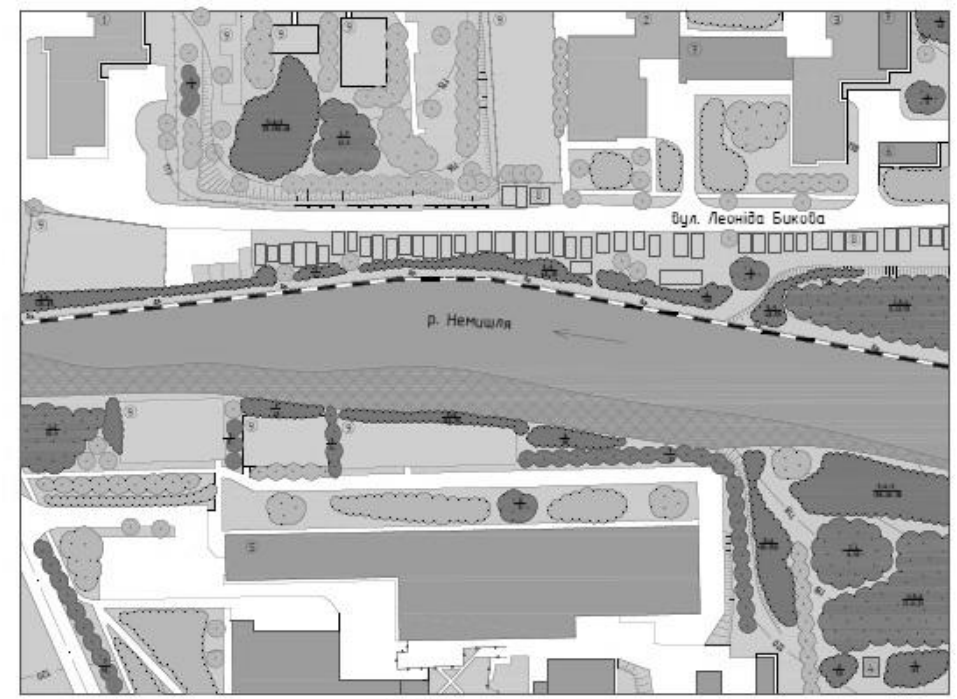

\section{Умовні позначення}

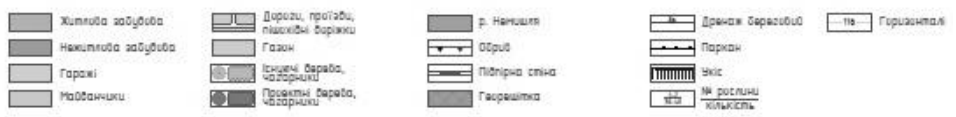

Рис. 6. Інженерний захист зсувонебезпечної берегової смуги уздовж річки Немишля в місті Харкові (фрагмент)

Інженерний захист даної ділянки берегової смуги виконується шляхом улаштування на правому березі, де спостерігається значний перепад висот, залізобетонної підпірної стінки на пальовому ростверку 3 прокладанням берегового дренажу у підошві стінки та влаштування об'ємної георешітки 3 посівом трав на лівому березі, де схил більш положистий (рис. 6).

У результаті проведення інженерного захисту берегову смугу можливо використовувати як рекреаційну зону для відпочинку населення. 


\section{Висновки}

У результаті аналізу зсувних процесів на території України виявлено, що поширення та розвиток зсувів має тенденцію до зростання, площі зсувонебезпечних зон за останні 30 років збільшились у 2-5 разів.

У Харківській області зафіксовано 1615 зсувів загальною площею

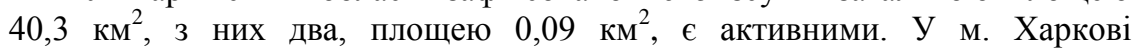
зсувонебезпечні території розташовані переважно на берегах річок Лопань, Харків та схилах ярів Олексіївська балка, Чуніхін Яр тощо.

Як проектна пропозиція запропоновано проведення інженерного захисту берегової смуги уздовж р. Немишля в місті Харкові.

\section{References}

1.Zakhyst vid nebezpechnykh heolohichnykh protsesiv, shkidlyvykh ekspluatatsiinykh vplyviv, vid pozhezhi. Zakhyst vid nebezpechnykh heolohichnykh protsesiv. Osnovni polo-zhennia proektuvannia : DBN V.1.1-24:2009. - Chynnyi vid 2011-01-01. - Kyiv : Minre-hionbud Ukrainy, 2010. - 108 s. (Derzhavni budivelni normy Ukrainy).

2.Zakhyst vid nebezpechnykh heolohichnykh protsesiv. Inzhenernyi zakhyst terytorii, budynkiv i sporud vid zsuviv ta obvaliv. Osnovni polozhennia : DBN V.1.1-397. - Chynnyi vid 01.07.97 r. - Kyiv : Derzhbud Ukrainy, 1998. - 47 s. (Derzhavni budivelni normy Ukrainy).

3.Kuzmenko E.D., Kryzhanivskyi Ye.I., Karpenko O.M., Zhuravel O.M. Dovhostrokovyi prohnoz zsuvnoi aktyvnosti na terytorii pravoberezhzhia Kyivskoho vodoskhovyshcha. Heodynamika, 2012. № 1(12)/2012. S. 93-102.

4.Kuzmenko E.D., Kryzhanivskyi Ye. I., Karpenko O.M., Zhuravel O.M. Pro-hnoz rozvytku zsuvnykh protsesiv yak faktor zabezpechennia nadiinosti ekspluatatsii truboprovodiv. Rozvidka ta rozrobka naftovykh i hazovykh rodovyshch, 2005. № 4(17). S. 24-35.

5.Kasiianchuk D.V. Statystychnyi analiz faktoriv pryrodnoi ta tekhnohennoi skladovoi rozvytku zsuviv. Visnyk Kharkivskoho natsionalnoho universytetu imeni V.N. Karazina. Seriia: Heolohiia - Heohrafiia - Ekolohiia, 2014. № 1128, Vyp. 41. S. 139148.

6.Claudio Margottini, Paolo Canuti, Kyoji Sassa (2013), Landslide Science and Practice. Volume 1 : Landslide Inventory and Susceptibility and Hazard Zoning. - New York - London: Springer International Publishing. 615 p.

7.Matjaž Mikoš, Binod Tiwari, Yueping Yin, Kyoji Sassa (2017), Advancing Culture of Living with Landslides. Volume 2 : Advances and Landslide Science. New York : Springer International Publishing. 1193 p.

8.Kyoji Sassa, Hiroshi Fukuoka, Fawu Wang, Gonghui Wang (2007), Progress in Landslide Science. Germany, Berlin : Springer Berlin Heidelberg New York. 375 p.

9.Agarwal, D.K., Krishna, A.P., Joshi, V., Kumar, K. and Palni, L.M.S. [Eds.] (1997), Perspectives of mountain Risk Engineering in the Himalayan region. Gyanodaya Prakashan, Nainital, p. 244.

10. Analitychnyi ohliad stanu tekhnohennoi ta pryrodnoi bezpeky v Ukraini za 2018 rik [Tekst] / Derzhavna sluzhba Ukrainy z nadzvychainykh sytuatsii, Ministerstvo 
ekolohii ta pryrodnykh resursiv Ukrainy, Natsionalna akademiia nauk Ukrainy. - Kyiv, 2018. $-278 \mathrm{~s}$.

11. Heneralnyi plan mista Kharkova [Elektronnyi resurs]. - URL : http://uga.kharkov.ua/uk/public-information/genplan-mista-harkova.html

12. Lynnyk I. E. Inzhenerna pidhotovka terytorii naselenykh mists: navch. posi-bnyk. Kharkiv : KhNAMH, 2004. 337 s.

\section{Список використаної літератури}

1.Захист від небезпечних геологічних процесів, шкідливих експлуатаційних впливів, від пожежі. Захист від небезпечних геологічних процесів. Основні положення проектування : ДБН В.1.1-24:2009. - Чинний від 2011-01-01. - Київ : Мінрегіонбуд України, 2010. - 108 с. (Державні будівельні норми України).

2.Захист від небезпечних геологічних процесів. Інженерний захист територій, будинків і споруд від зсувів та обвалів. Основні положення : ДБН В.1.1-3-97. Чинний від 01.07.97 p. - Київ : Держбуд України, 1998. - 47 с. (Державні будівельні норми України).

3.Кузьменко Е.Д., Крижанівський Є.І., Карпенко О.М., Журавель О.М. Довгостроковий прогноз зсувної активності на території правобережжя Київського водосховища. Геодинаміка, 2012. № 1(12)/2012. С. 93-102.

4.Кузьменко Е.Д., Крижанівський Є. І., Карпенко О.М., Журавель О.М. Прогноз розвитку зсувних процесів як фактор забезпечення надійності експлуатації трубопроводів. Розвідка та розробка нафтових $і$ газових родовищ, 2005. № 4(17). С. 24-35.

5.Касіянчук Д.В. Статистичний аналіз факторів природної та техногенної складової розвитку зсувів. Вісник Харківського начіонального університету імені B.Н. Каразіна. Серія: Геологія - Географія - Екологія, 2014. № 1128, Вип. 41. С. 139-148.

6.Claudio Margottini, Paolo Canuti, Kyoji Sassa (2013), Landslide Science and Practice. Volume 1 : Landslide Inventory and Susceptibility and Hazard Zoning. - New York - London: Springer International Publishing. 615 p.

7.Matjaž Mikoš, Binod Tiwari, Yueping Yin, Kyoji Sassa (2017), Advancing Culture of Living with Landslides. Volume 2 : Advances and Landslide Science. New York : Springer International Publishing. 1193 p.

8.Kyoji Sassa, Hiroshi Fukuoka, Fawu Wang, Gonghui Wang (2007), Progress in Landslide Science. Germany, Berlin : Springer Berlin Heidelberg New York. 375 p.

9.Agarwal, D.K., Krishna, A.P., Joshi, V., Kumar, K. and Palni, L.M.S. [Eds.] (1997), Perspectives of mountain Risk Engineering in the Himalayan region. Gyanodaya Prakashan, Nainital, p. 244.

10. Аналітичний огляд стану техногенної та природної безпеки в Україні за 2018 рік [Текст] / Державна служба України з надзвичайних ситуацій, Міністерство екології та природних ресурсів України, Національна академія наук України. Київ, 2018. - 278 с.

11. Генеральний план міста Харкова [Електронний ресурс]. - URL : http://uga.kharkov.ua/uk/public-information/genplan-mista-harkova.html

12. Линник I. Е. Інженерна підготовка територій населених місць: навч. посібник. Харків : ХНАМГ, 2004. 337 с. 